JTIEE, Vol 3 No 1, 26 Mei 2019

\title{
MENINGKATKAN PEMAHAMAN KONSEP BILANGAN BULAT MELALUI MODEL PEMBELAJARAN KOOPERATIF TIPE TGT MENGGUNAKAN MEDIA POTAKA PESERTA DIDIK KELAS V SDN DERMO
}

\author{
Nur Halimatus Sa'diyah' ${ }^{1)}$ \\ Pendidikan Guru Sekolah Dasar, Universitas Muhammadiyah Gresik \\ nouralim297@gmail.com \\ Arissona Dia Indah Sari ${ }^{2)}$ \\ Pendidikan Guru Sekolah Dasar, Universitas Muhammadiyah Gresik \\ arissona@umg.ac.id
}

\begin{abstract}
Abstrak
Jenis penelitian ini menggunakan penelitian tindakan kelas. Terdiri dari dua siklus yaitu: perencanaan, pelaksanaan, pengamatan, dan refleksi. Subjek yang dipilih oleh peneliti peserta didik kelas V SDN Dermo Benjeng Gresik, tahun ajaran 2018/2019 yang berjumlah 15 peserta didik. Hasil penelitian ini menunjukkan, Pada siklus I observasi aktivitas peserta didik rata-rata 51,43\%, dan pada siklus II menjadi 75,33\%. Sedangkan hasil tes pemahaman konsep pada siklus I nilai rata-rata klasikal 53\% dan pada siklus II nilai rata-rata $80 \%$. Peningkatan terjadi karena adanya perbaikan pada siklus II dengan membuat pembelajaran lebih menarik. Berdasarkan hasil penelitian dapat disimpulkan bahwa menggunakan model kooperatif tipe TGT dan media POTAKA dapat meningkatkan pemahaman konsep pada Mata Pelajaran Matematika Peserta Didik Kelas V SDN Dermo materi Bilangan Bulat.
\end{abstract}

Kata Kunci : Bilangan Bulat, Kooperatif Tipe TGT, Media POTAKA.

\begin{abstract}
This type of research uses classroom action research. Consists of 2 cycles, namely: planning, implementation, observation and reflection. The subject chosen by the researcher is the fifth grade student of SDN Dermo-Benjeng-Gresik, the academic year 2018/2019 which amounts to 15 students. The results of this study showed that in the first cycle 1 the observation of the activities of students averaged $51,43 \%$ and in the second cycle II became 75,33\%. While the results of the concept understanding test in the first cycle I the classical average value of 53\% and in the second cycle II the average value was $80 \%$. In the crease occurred because of improvement in the second cycle II by making learning more interesting. Based on the results of the study it can be concluded that using the cooperative type TGT models and POTAKA media can improve the understanding of concepts on mathematics subjects in class V SDN Dermo integer material.
\end{abstract}

Keywords : Integers, Cooperative Type TGT, POTAKA Media

\section{A. PENDAhuluan}

Pembelajaran pada hakikatnya merupakan suatu kombinasi yang tersusun meliputi unsur-unsur manusiawi, material, fasilitas, perlengkapan, dan prosedur yang saling mempengaruhi mencapai tujuan pembelajaran (Hamalik, 2014: 57). Sedangkan menurut (Majid, 2013: 5) pembelajaran merupakan kegiatan terencana yang mengkondisikan atau merangsang seseorang agar bisa belajar dengan baik agar sesuai dengan tujuan pembelajaran. Dari kedua pendapat di atas disimpulkan bahwa pembelajaran merupakan suatu kegiatan terencana atau tersusun melalui unsur-unsur manusiawi, material, fasilitas, perlengkapan, prosedur yang saling mempengaruhi dan merangsang seseorang agar bisa belajar dengan baik untuk mencapai tujuan pembelajaran.

Guru dan peserta didik memiliki peran yang sangat penting pada saat proses pembelajaran berlangsung guna mencapai tujuan pembelajaran. Ketercapaian suatu tujuan pembelajaran dapat diketahui dari hasil tes pemahaman konsep yang diperoleh peserta didik. Hal itu juga berlaku pada pembelajaran matematika, ketercapaian tujuan pembelajaran matematika ditentukan dari proses pembelajarannya yang diukur dari hasil belajar yang diperoleh peserta didik. Hal ini sependapat dengan Suherman (2003: 71) bahwa pembelajaran matematika ditekankan pada proses dan hasil berpikir. Oleh karena itu pembelajaran matematika harus memperhatikan proses dan hasil belajar guna mencapai mencapai tujuan pembelajaran.

Mata pelajaran matematika bertujuan agar peserta didik memahami konsep matematika, menjelaskan keterkaitan antara konsep dan mengaplikasikan konsep atau algoritma, secara luwes, akurat, efisien, dan tepat, dalam pemecahan masalah (Depdiknas, 2006: 24). Sedangkan menurut Heruman (2008: 3) pemahaman konsep yaitu pembelajaran Memahami suatu konsep matematika. Dari beberapa pendapat diatas dapat disimpulkan 
bahwa mata pelajaran matematika bertujuan agar peserta didik memahami suatu konsep matematika yang menjelaskan keterkaitan antara konsep dan mengaplikasikan konsep dalam pemecahan masalah.

Pembelajaran matematika dikelas $\mathrm{V}$ terdiri beberapa konsep, salah satunya adalah bilangan bulat. Bilangan adalah suatu ide yang digunakan untuk menggambarkan atau mengabstraksi banyaknya anggota suatu himpunan (Khairunnisa, 2015: 84). Bilangan dibagi menjadi sifat-sifat operasi hitung, bilangan bulat yaitu bilangan yang terdiri dari bilangan positif dan negatif. Dalam penelitian ini, peneliti memilih konsep bilangan bulat sebab pada pokok bahasan tentang bilangan bulat ini hasil belajar peserta didik masih tergolong rendah. Rendahnya hasil peserta didik belajar menunjukkan tingkat pemahaman konsep tentang bilangan bulat masih rendah.

Berdasarkan hasil observasi yang dilakukan peneliti pada tanggal 16 Januari 2018 yang dilaksanakan di SDN Dermo Benjeng Gresik. Peneliti menemukan permasalahan yaitu peserta didik kurang memahami penjelasan dari guru pada saat proses pembelajaran materi matematika dan guru hanya menggunakan metode cerama. Sedangkan hasil wawancara terhadap guru kelas, pada proses pembelajaran diperoleh data berupa nilai KKM sebesar 70, ketuntasan belajar matematika dari 15 peserta didik diperoleh 68,39\% atau 9 peserta didik yang telah tuntas, sedangkan diperoleh $31,61 \%$ atau 6 peserta didik yang tidak tuntas. Disimpulkan dari hasil pembelajaran matematika ketuntasan pembelajaran peserta didik di SDN Dermo masih rendah.

Rendahnya nilai matematika kemungkinan disebabkan oleh pemilihan model pembelajaran yang kurang tepat. Hal ini menyebabkan pembelajaran menjadi membosankan, pasif dan monoton. Oleh karena itu diperlukan pemilihan model pembelajaran dan media yang tepat untuk meningkatkan pemahaman konsep pada peserta didik. Model pembelajaran dan media tersebut yaitu model kooperatif tipe TGT dan media POTAKA.

Pembelajaran kooperatif tipe TGT (Teams Games Tournament) dan media pembelajaran POTAKA (pohon pintar kartu). Sehingga mampu menarik perhatian peserta didik, membuat peserta didik aktif, dengan demikian pemahaman peserta didik terhadap materi bilangan bulat menjadi meningkat. Model pembelajaran kooperatif tipe TGT (Teams Games Tournament) dengan kolaborasi media pembelajaran POTAKA (pohon pintar kartu).

Rusman, (2014: 224) mejelaskan bahwa pembelajaran kooperatif tipe TGT (Teams Games Tournament) merupakan salah satu tipe pembelajaran kooperatif yang menempatkan peserta didik dalam kelompok-kelompok belajar yang beranggotakan 5 sampai 6 orang peserta didik yang memiliki kemampuan, jenis kelamin, suku kata atau ras yang berbeda. Pembelajaran kooperatif tipe TGT ini melibatkan semua peserta didik tanpa membedakan status dalam bekerja kelompok serta mengandung unsur permainan. Keuntungan menggunakan model pembelajaran kooperatif tipe $T G T$ meningkatkan minat belajar peserta didik untuk belajar bertanya dan mengeluarkan pendapat dalam proses pembelajaran dan peserta didik dapat belajar dari peserta didik lainnya. Sehingga pembelajaran yang dilaksanakan dengan sendirinya dapat memberikan makna bagi peserta didik dan mampu berkonsultasi dengan teman sebaya.

Keterkaitan pemahaman konsep pada materi bilangan bulat dapat meningkat dengan memilih model pembelajaran yang dapat memberikan kesempatan kepada peserta didik untuk berkembang sesuai dengan kemampuan peserta didik. Salah satu model pembelajaran yang memungkinkan peserta didik dapat memahami konsep bilangan bulat dengan baik adalah model pembelajaran TGT, merupakan model pembelajaran yang dilaksanakan didalam kelas dimanah peserta didik membutuhkan kerja sama dalam kelompok kecil yang menggabungkan kemampuan peserta didik dalam kelompok belajar. Sehingga peserta didik akan lebih mudah untuk memahami konsep bilangan bulat.

Pada proses pembelajaran matematika materi bilangan bulat peneliti menerapkan model pembelajaran kooperatif tipe TGT dengan menggunakan media POTAKA (pohon pintar kartu). Pohon pintar yaitu suatu alat permainan menggunakan sebatang pohon yang telah dibentuk semenarik mungkin serta menggunakan angka sehingga dapat membantu anak dalam meningkatkan potensi dan kecerdasan yang ada dalam diri anak agar berkembang secara optimal (Windarti, 2013: 24). Sedangkan menurut Handayani, (2013: 8) kartu adalah media bergambar yang terbuat dari kertas tebal atau karton yang mempunyai ukuran tertentu di tengahnya terdapat gambar materi yang sesuai dengan pokok bahasan. Media pembelajaran pohon pintar kartu untuk meningkatkan pembelajaran lebih menarik, peserta didik aktif dalam proses pembelajaran dan peserta didik antusias pada mata pelajaran matematika. POTAKA dalam penelitian ini salah satu bentuk media yang terbuat dari batang pohon, dan kertas duhplex. Ditengahnya kertas duhplex terdapat kartu bilangan bulat yang terbuat dari kertas HVS berbentuk persegi panjang dan dihias sebagus mungkin. Sehingga pembelajaran matematika dikelas $\mathrm{V}$ dapat dimengerti dan dipahami oleh peserta didik, juga media ini dapat menarik perhatian peserta didik saat proses pembelajaran berlangsung.

Berdasarkan penelitian terdahulu yang dilakukan Shofiana (2010) meneliti tentang penerapan pembelajaran kooperatif tipe $T G T$ untuk meningkatkan prestasi belajar mata pelajaran ips, dalam penelitian Shofiana ini prestasi belajar peserta didik mengalami peningkatan yang cukup. Pada penelitian Faidarini 
(2011) meneliti tentang meningkatkan hasil belajar matematika dengan menggunakan alat peraga kubus, dalam penelitian Faidarini ini menunjukkan bahwa aktivitas peserta didik selama mengikuti pembelajaran mengalami peningkatan. Tujuan peneliti untuk mengetahui hasil belajar peserta didik dengan memberikan soal - soal secara rutin agar peserta didik dapat mengerjakan soal ulangan dengan benar. Hasil uraian di atas maka peneliti tertarik untuk meneliti dengan judul "Meningkatkan pemahaman konsep bilangan bulat melalui model pembelajaran kooperatif tipe TGT dengan menggunakan media POTAKA (pohon pintar kartu) peserta didik kelas V SDN Dermo"

\section{B. METODE}

\section{Jenis Penelitian}

Model penelitian yang digunakan dalam penelitian ini adalah penelitian Tindakan Kelas (PTK). Penelitian Tindakan Kelas (PTK) adalah penelitian yang sengaja dilakukan di kelas karena adanya suatu permasalah dengan tujuan dapat mengatasi masalah tersebut dan meningkatkan pemahaman konsep menjadi meningkat. Penelitian ini dilaksanakan di SDN Dermo Benjeng Gresik, yang beralamatkan di Ds. Dermo Kec.Benjeng Kab.Gresik. Penelitian dilaksanakan pada semester I (Ganjil) tahun pelajaran 20182019, pada tanggal 8 Agustus - 10 Agustus 2018. Subjek penelitian ini adalah peserta didik adalah kelas V SDN Dermo Benjeng Gresik Tahun pelajaran 2018/2019 Dengan jumlah 15 peserta didik yang terdiri dari 13 peserta didik laki-laki dan 2 peserta didik perempuan. Pada peserta didik berusia 10- 11 tahun dengan karakter kemampuan peserta didik yang berbeda - beda. Prosedur penelitian yang dilakukan oleh peneliti berdasarkan model penelitian tindakan kelas dengan melalui empat langkah yaitu perencanaan, pelaksanaan tindakan, pengamatan, dan refleksi. Pada tahap perencanaan ini peneliti melakukan tindakan meliputi: (1) menentukan jadwal kegiatan pembelajaran, silabus, Rencana Pelaksanaan Pembelajaran (RPP), membuat lembar observasi, (2) menganalisis kurikulum KTSP untuk mengetahui Kompetensi Inti dan Kompetensi Dasar, (3) menyusun perangkat pembelajaran yaitu silabus, Rencana Pelaksanaan Pembelajaran (RPP), menyusun lembar kerja peserta didik, merancang lembar observasi aktivitas peserta didik dan menyusun alat evaluasi pembelajaran yaitu tes pemahaman konsep, menyiapkan penghargaan, model, media dan bahan ajar (4) merancang prosedur kegiatan pembelajaran dengan model pembelajaran kooperatif tipe TGT dan menggunakan media POTAKA mata pelajaran Matematika materi bilangan bulat, (5) membuat lembar kerja peserta didik untuk melakukan kegiatan penyelidikan atau pemecahan masalah, (6) mempersiapkan lembar observasi aktivitas peserta didik dan lembar tes pemahaman konsep. Tahap pelaksanaan tindakan peneliti melaksanakan sesuai dengan yang direncanakan dalam RPP pada mata pelajaran MATEMATIKA materi bilangan bulat. Tahap pengamatan terhadap peserta didik pada proses pembelajaran berlangsung sesuai dengan rencana pembelajaran yang di buat peneliti termasuk ketepatan peserta didik dalam mengerjakan soal matematika. Dan terakhir tahap refleksi ini dilakukan untuk memperbaiki kekurangan selama proses pembelajaran dan melakukan evaluasi di akhir pembelajaran.

2. Data Dan Metode Pungumpulan Data

Data yang digunakan oleh peneliti disini adalah: (1) hasil tes tulis yang dilakukan untuk meningkatkan pemahaman peserta didik setelah menggunakan model kooperatif tipe TGT dengan menggunakan media POTAKA pada pembelajaran matematika materi bilangan bulat, (2) hasil obeservasi yang dilakukan untuk mengamati aktifitas belajar peserta didik pada saat kegiatan pembelajaran. Dan metode pengumpulan data yaitu metode yang dilakukan peneliti untuk memperoleh data yang dibutuhkan, maka teknik yang dilakukan peneliti adalah sebagai berikut : (1) metode tes digunakan untuk mengukur tes pemahaman konsep peserta didik meliputi aspek kognitif dengan soal tes yang telah peneliti ujikan berupa uraian 5 soal. hal ini dilakukan untuk memperoleh data yang akurat mengenai hasil pemahaman konsep peserta didik. (2) observasi adalah metode pengumpulan data yang berupa pengamatan setiap kejadian yang berhubungan dengan kegiatan peserta didik yang terdapat pada proses pembelajaran berlangsung dan mencatatnya dengan alat observasi berupa tentang hal-hal yang akan diamati atau diteliti. Observasi juga menjadi instrument utama yang digunakan untuk mengumpulkan data kegiatan pembelajaran berupa perilaku peserta didik. Peneliti akan menjelaskan mengenai aktivitas observasi yang diamati yaitu : Observasi aktivitas peserta didik, yaitu mengamati, memantau pada saat proses pembelajaran.

3. Instrumen Penelitian

Adapun instrumen yang digunakan peneliti pada penelitian ini, tentang pemahaman dan aktivitas peserta didik meliputi lembar aktivitas peserta didik, dan lembar tes pemahaman konsep. Lembar observasi aktivitas peserta didik digunakan untuk mengobservasi aktivitas peserta didik selama pembelajaran, dan lembar tes pemahaman konsep ini dibuat berdasarkan materi yang diajarkan. 
4. Analisis Data

Analisis data pada penelitian ini menggunakan dua metode, yaitu : observasi dan tes pemahaman konsep guna untuk mengetahui kemampuan peserta didik dalam pembelajaran matematika. Analisis data yang dilakukan oleh peneliti adalah :

(1) Data observasi

Data aktifitas peserta didik dianalisis dengan menggunakan rumus :

Keterangan :

$$
\mathrm{P}=\frac{f}{N} \times 100 \%
$$

$\mathrm{P}:$ Persentase

$f:$ Jumlah seluruh skor jawaban yang diperoleh

$\mathrm{N}$ : jumlah skor maksimal semua komponen yang diambil (Arikunto, , $2006: 135$ )

Proses belajar yang telah diklasifikasikan ke dalam bentuk pensekoran nilai peserta didik dengan menggunakan kriteria keberhasilan sebagai berikut:

\begin{tabular}{|l|l|}
\hline Kriteria Penilaian & \multicolumn{1}{|c|}{ Keterangan } \\
\hline $50 \%-59 \%$ & Kurang \\
\hline $60 \%-69 \%$ & Cukup \\
\hline $70 \%-79 \%$ & Baik \\
\hline $80 \%-90 \%$ & Sangat Baik \\
\hline
\end{tabular}

(Sudjana dalam Fathnawati, 2011: 6)

(2) Data tes pemahaman konsep

Data tes pemahaman konsep peserta didik dianalisis dengan menggunakan rumus

a. Ketuntasan individual

Ketuntasan belajar secara individual dihitung dengan rumus sebagai berikut :

$$
\begin{aligned}
& \text { Nilai }=\frac{\text { skor yang diperoleh }}{\text { skor maksimal }} \times 100 \\
& \text { (Arikunto, , 2006: 134) }
\end{aligned}
$$

Seorang peserta didik dikatakan tuntas secara individual apabila siswa nilai $\geq$ KKM yaitu 70 sesuai dengan standart ketuntasan belajar di SDN Dermo

b. Ketuntasan klasikal

Ketuntasan belajar secara klasikal dihitung dengan rumus sebagai berikut :

$$
\text { Ketuntasan klasikal }=\frac{\text { siswa yang tuntas belajar }}{\text { seluruh siswa }} \times 100 \%
$$

(Arikunto, 2006: 134)

Ketuntasan tes pemahaman konsep secara klasikal di SDN Dermo pada materi bilangan bulat dengan pencapaian minimal $70 \%$ dari jumlah peserta didik telah mencapai nilai $\mathrm{KKM} \geq 70 \%$.

\section{HASIL DAN PEMBAHASAN}

\section{Deskripsi Hasil Penelitian Siklus I}

Siklus I terdiri dari satu kali pertemuan dengan menggunakan model pembelajaran kooperatif tipe TGT dan media POTAKA. Adapun tahapan perencanaan sebelum melakukan penelitian yakni menentukan waktu, Membuat perangkat menggunakan model pembelajaran kooperatif tipe TGT dan media POTAKA. Adapun hasil penelitian pada siklus I yakni:

\section{Hasil Observasi Aktivitas Peserta Didik}

Data hasil observasi aktivitas peserta didik selama proses pembelajaran berlangsung diperoleh dari hasil pengamatan mengunakan instrumen lembar pengamatan peserta didik yakni:

Aktivitas peserta didik Siklus I : $\mathrm{P}=\frac{\mathrm{f}}{\mathrm{N}} \times 100 \%$

$$
\begin{aligned}
& \mathrm{f}: \text { jumlah skor yang didapat siswa } \\
& \mathrm{N}: \text { jumlah skor maksimal } \\
& =\frac{25}{60} \times 100 \% \\
& =41 \% \\
& \quad \mathrm{~N}=4 \times 15=60
\end{aligned}
$$




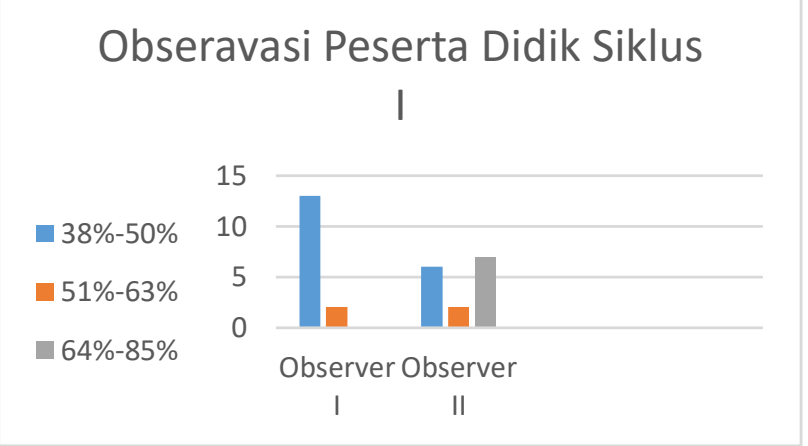

Dari hasil tersebut dapat dijelaskan bahwa secara keseluruhan pengamatan untuk seluruh aktivitas peserta didik dalam penggunaan model pembelajaran kooperatif tipe TGT dengan media POTAKA untuk meningkatkan pemahaman konsep bilangan bulat pada siklus I. Untuk mengetahui rata-rata dari observer 1 dan 2 dapat dihitung dengan aktivitas peserta didik jumlah dari observer 1 dan 2 dibagi 2 sedangkan nilai rata-rata keseluruhan $51,43 \%$. Hasil ini menunjukkan bahwa aktivitas peserta didik pada siklus I ini belum mencapai persentase indikator keberhasilan pada aktivitas peserta didik yaitu 70\%.

\section{Hasil Tes Pemahaman Konsep Siklus I}

Hasil tes pemahaman konsep pada proses pembelajaran siklus I yang didapatkan dari perhitungan rata-rata kelas sebesar 68,7. Sehingga diperoleh bahwa peserta didik yang mendapatkan nilai lebih dari 70 sebanyak 8 peserta didik, sedangkan yang mendapatkan nilai kurang dari 70 sebanyak 7 peserta didik.

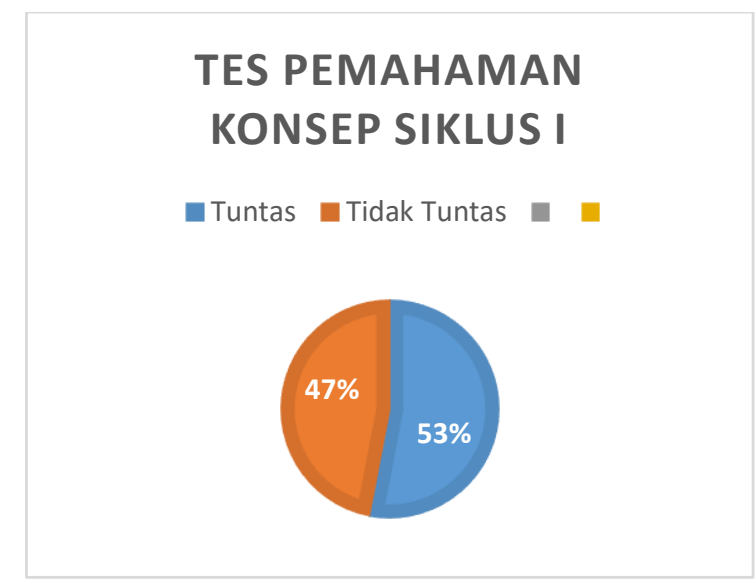

a. Hasil Pemahaman Konsep Secara Individu

Keterangan :

Tuntas $=\mathrm{T}$

Tidak Tuntas $=$ TT

Jumlah peserta didik yang tuntas $\quad: 53 \%$

Jumlah peserta didik yang tidak tuntas $: 47 \%$

Ketuntasan peserta didik secara individu mencapai 8 peserta didik dari 15 peserta didik

b. Ketuntasan Klasikal

Analisis data ketuntasan klasikal berdasarkan ketuntasan individual dihitung sebagai berikut :

Ketuntasan secara klasikal dengan menggunakan model kooperatif tipe TGT dan media POTAKA pada materi sifat-sifat operasi hitung bilangan bulat di kelas V SDN Dermo yaitu:

Jumlah peserta didik yang tuntas : 8

Jumlah peserta didik yang tidak tuntas : 7

Seluruh jumlah peserta didik : 15

Presentase ketuntasan penguasaan konsep secara klasikal

$$
\begin{aligned}
& \frac{\text { siswa yang tuntas belajar }}{\text { seluruh Peserta didik }} \times 100 \% \\
& =\frac{8}{15} \times 100 \% \\
& =53 \%
\end{aligned}
$$


Data dari tes pemahaman konsep pada siklus I diperoleh ketuntasan belajar dari 15 peserta didik. 8 peserta didik memperoleh nilai $\leq 70$ dengan presentase $53 \%$ dan 7 peserta didik memperoleh nilai $\geq$ 70 dengan presentase $47 \%$, dari hasil tes pemahaman konsep dapat diketahui bahwa tes pemahaman konsep pada siklus I belum mencapai kriteria ketuntasan klasikal yaitu 70\%

\section{Hasil Observasi Peserta Didik Siklus II}

Lembar observasi aktivitas peserta didik selama proses pembelajaran berlangsung diperoleh dari hasil pengamatan menggunakan instrumen lembar pengamataran peserta didik siklus II. Adapun hasil pengamatan peserta didik sebagai berikut ini:

Aktivitas peserta didik Siklus II : $\mathrm{P}=\frac{\mathrm{f}}{\mathrm{N}} \times 100 \%$

$$
\begin{aligned}
& \mathrm{f} \text { : jumlah skor yang didapat siswa } \\
& \mathrm{N} \text { : jumlah skor maksimal } \\
& =\frac{44}{73} \times 100 \% \\
& =41 \% \\
& \mathrm{~N}=4 \times 15=60
\end{aligned}
$$

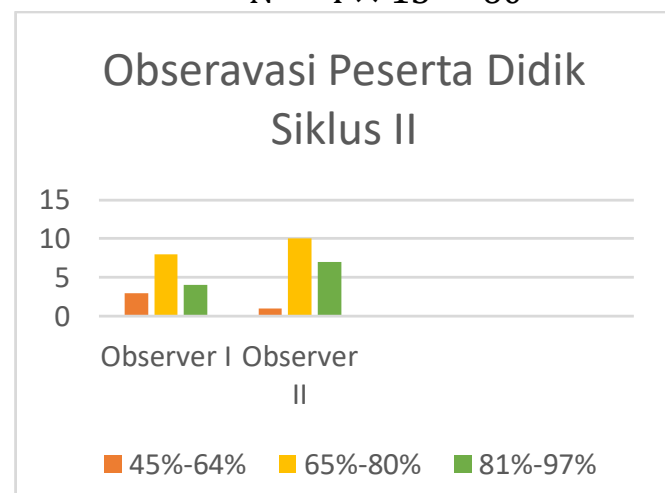

Dari hasil tersebut dapat dijelaskan bahwa secara keseluruhan pengamatan untuk seluruh aktivitas peserta didik dalam penggunaan model pembelajaran kooperatif tipe TGT dengan media POTAKA untuk meningkatkan pemahaman konsep bilangan bulat pada siklus II. Untuk mengetahui rata-rata dari observer 1 dan 2 dapat dihitung dengan aktivitas peserta didik dari jumlah observer 1 dan 2 dibagi 2 sedangkan nilai rata-rata keseluruhan $75,33 \%$. Hasil ini menunjukkan bahwa aktivitas peserta didik pada siklus II dalam menggunakan model pembelajaran kooperatif tipe TGT dan menggunakan media POTAKA untuk meningkatkan pemahaman konsep mata pelajaran Matematika telah mencapai presentase indikator keberhasilan pada aktivitas peserta didik yaitu $70 \%$ dari seluruh aktivitas peserta didik

\section{Hasil Tes Pemahaman Konsep Siklus II}

Hasil tes pemahaman konsep pada proses pembelajaran siklus II yang didapatkan dari perhitungan rata-rata kelas sebesar 86,7. Sehingga diperoleh bahwa peserta didik yang mendapatkan nilai lebih dari 70 sebanyak 12 peserta didik, sedangkan yang mendapatkan nilai kurang dari 70 sebanyak 3 peserta didik.

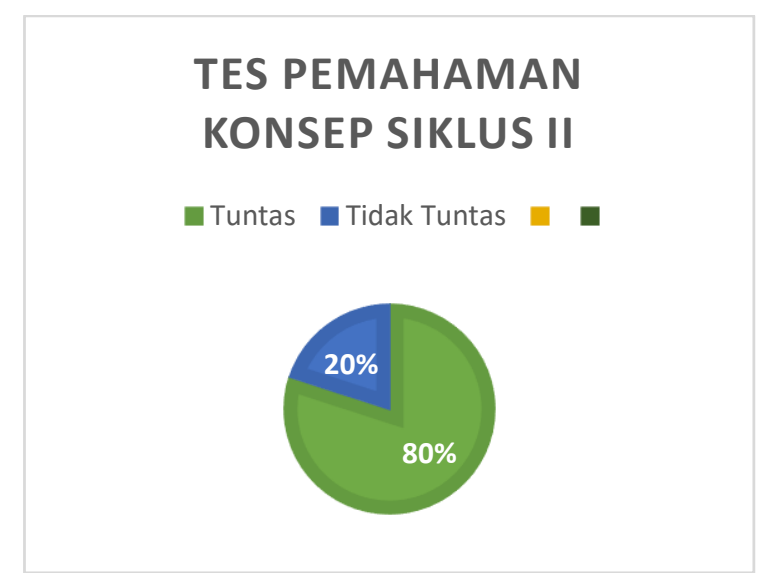


JTIEE, Vol 3 No 1, 26 Mei 2019

a. Hasil Pemahaman Konsep Secara Individu

Keterangan :

Tuntas $=\mathrm{T}$

Tidak Tuntas $=$ TT

Jumlah peserta didik yang tuntas $\quad: 80 \%$

Jumlah peserta didik yang tidak tuntas $: 20 \%$

Berdasarkan table diatas ketuntasan peserta didik secara individu mencapai 12 peserta didik dari 3 peserta didik.

b. Ketuntasan Klasikal

Analisis data ketuntasan klasikal berdasarkan ketuntasan individual dihitung sebagai berikut :

Ketuntasan secara klasikal dengan menggunakan model kooperatif tipe TGT dan media POTAKA pada materi sifat-sifat operasi hitung bilangan bulat di kelas V SDN Dermo yaitu:

Jumlah peserta didik yang tuntas : 12

Jumlah peserta didik yang tidak tuntas : 3

Seluruh jumlah peserta didik : 15

$$
\begin{aligned}
& =\frac{12}{15} \times 100 \% \\
& =80 \%
\end{aligned}
$$$$
\frac{\text { siswa yang tuntas belajar }}{\text { seluruh Peserta didik }} \times 100 \%
$$

Data dari tes pemahaman konsep pada siklus II diperoleh rata-rata kelasikal $80 \%$ ketuntasan mengalami peningkatan. Jumlah hasil tes pemahaman konsep pada peserta didik yang memperoleh $\geq$ 70 sebanyak 12 peserta didik dikategorikan telah tuntas belajar, dan 3 peserta didik yang belum tuntas. Hal ini menunjukkan tes pemahaman konsep pada siklus II telah mencapai ketuntasan belajar yaitu dengan persentase $80 \%$ dan persentase ketidak tuntasan adalah $20 \%$.

\section{KESIMPULAN}

Berdasarkan hasil penelitian dan pembahasan yang dilakukan pada peserta didik kelas V SDN Dermo Benjeng Gresik tahun pelajaran 2018/2019, maka dapat disimpulkan bahwa pembelajaran bilangan bulat dengan model pembelajaran koopratif tipe TGT menggunakan media POTAKA dapat meningkatkan keaktifan peserta didik. Dengan lembar observasi aktivitas peserta didik pada siklus I rata-rata 51,43\% dan pada siklus II menjadi 75,33\%. Disimpulkan bahwa penerapan model pembelajaran kooperatif tipe TGT menggunakan media POTAKA pada mata pelajaran matematika materi bilangan bulat kelas V SDN dermo telah berhasil diterapkan dengan adanya peningkatan pada setiap siklusnya.

Pembelajaran bilangan bulat dengan menggunakan model pembelajaran kooperatif tipe TGT menggunakan media POTAKA dapat meningkatkan pemhaman konsep. Hasil tes pemahan konsep pada siklus I nilai klasikal 53\% dan pada siklus II nilai rata-rata klasikal $80 \%$. Peningkatan terjadi karena adanya perbaikan pada siklus II, dari siklus I dan siklus II lembar observasi meningkat menjadi 23,90\% dan tes pemahaman konsep siklus 1 dan siklus II meningkat menjadi $80 \%$.

\section{E. DAFTAR PUSTAKA}

Arikunto, S. (2006). Penelitian Tindakan Kelas. Jakarta : PT Bumi Aksara.

Arikunto, S. (Februari 2014). Penelitian Tindakan Kelas. Jakarta : PT Bumi Aksara.

Arniati, Y. (September 2013). Peningkatan Hasil Belajar Matematika Melalui Metode STAD Bagi Siswa Kelas IV SDN Banyuurip 02 Kecamatan Margorejo Kabupaten Pati . PGSD, Universitas Muhammadiyah Surakarta, 3.

Arsyad, A. (Juni 2015). Media Pembelajaran. Jakarta : Rajawali.

Depdiknas. (2006). Kurikulum Tingkat Satuan Pendidikan. Jakarta : Depdiknas.

Faidarini, O. (2011). Upaya Meningkatkan Hasil Belajar Matematika Materi Volume Kubus Dan Balok Dengan Menggunakan Alat Peraga Kubus Satuan Pada Siswa Kelas V Sekolah Dasar Attarbiyah Surabaya. PGSD, Universitas Negeri Surabaya

Hamalik, O. (April 2014). Kurikulum dan Pembelajaran. Jakarta : PT Bumi Aksara.

Handayani, I. R. (Juli 2013). Penggunaan Media Kartu Bergambar Untuk Meningkatkan Hasil Belajar Peninggalan Sejarah Pada Siswa Kelas IV Di Minu Curungrejo Kepanjen. Program Studi Pendidikan Guru Madrasah Ibtidaiyah, Universitas Islam Negeri Mulana Malik Ibrahim Malang.

Heruman. (Juni 2008). Model Pembelajaran Matematika di Sekolah Dasar. Boyke Ramdhani: Bandung : PT Remaja Rosdakarya. 
Isrotun, U. (Februari 2014). Peningkatan Pemahaman Konsep Matematika MelaluiI Penerapan Pembelajaran Realistik (PTK Pada Siswa Kelas VIII H Semester Genap MTs Negeri Surakarta II. 01.

Khairunnisa, A. (Juli 2015). Matematika Dasar. Jakarta PT Raja Grafindo Persada.

Majid, A. (Maret 2013). Strategi Pembelajaran. Engkus Kuswandi: Bandung : PT Remaja Rosdakarya.

Maolani, R. (Juni 2015). Metodologi Penelitin Pendidikan. Jakarta : PT Raja Grafindo Persada.

Muhsetyo, G. (April 2007). Pembelajaran Matematika SD. Jakarta : Universitas Terbuka.

Murizal, A. (2012). Pemahaman Konsep Matematis Dan Model Pembelajaran. Vol. 1 No. 1, 18.

Ngalimun. (Januari 2017). Strategi Pembelajaran. Yogyakarta : Parama Ilmu.

Rusman. (April 2014). Model-Model Pembelajaran. Jakarta : PT Raja Grafindo Persada.

Sagala, S. (Oktober 2014). Konsep dan Makna Pembelajaran. Bandung : Alfabeta.

Sanjaya, W. (Oktober 2009). Penelitian Tindakan Kelas. Jakarta : PT Fajar Interpratama.

Suherman, E. (Agustus 2003). Strategi Pembelajaran Matematika Kontemporer. Universitas Pendidikan Indonesia.

Sumanto. (Juli 2008). Gemar Matematika. PT Intan Pariwara.

Suyono, \&. H. (2016). Belajar dan Pembelajaran. Bandung : PT Remaja Rosdakarya.

Utari, V. (2012). Peningkatan Kemampuan Pwmahaman Konsep Melalui Pendekatan PMR Dalam Pokok Bahasan Prisma Dan Limas. Jurnal Pendidikan Matematika, Vol.1No.1, hal : 34.

Wahyudin. (Januari 2011). Fondasi dan Bukti Matematika. Jakarta : Universitas Terbuka.

Windarti, I. (2013). Penerapan Model Pembelajaran Kooperatif Tipe TGT Berbantuan Pohon Pintar Untuk Meningkatkan Hasil Belajar Matematika Pada Siswa Kelas V SD Negeri Gerlang Kabupaten Batang. Universitas Kristen Satyawacana.

Yusuf, S. (Maret 2017). Psikologi Perkembangan Anak dan Remaja. Bandung : PT Remaja Rosdakarya 